\title{
Influence of Entrepreneurial Orientation on the Profitability of Real Estate Firms in South West, Nigeria
}

\section{Edamisan Olowofeso}

Department of Entrepreneurship, School of Management Technology, The Federal University of Technology, Akure, Nigeria.

eolowofeso@futa.edu.ng,_www.orcid.org/0000-0001-6927-2600

\section{Oyewale Julius Ojo}

Department of Project Management Technology, School of Management Technology, The Federal University of Technology, Akure, Nigeria.

ojojo@futa.edu.ng, www.orcid.org/0000-0001-9321-1824

\section{Modupe Olayinka Ajayi}

Department of Project Management Technology, School of Management Technology, The Federal University of Technology, Akure, Nigeria.

moajayi@futa.edu.ng,www.orcir.org/0000-0001-8504-6064

\begin{abstract}
The study examined the effect of Entrepreneurial Orientation (EO) on the profitability of real estate firms in the South West, Nigeria. This was with a view to determine the relationship that exists between the EO- dimensions and the profitability of real estate firms. Data were collecting through questionnaire administration and analysed using both descriptive and inferential statistics. Finding of the study revealed that EO has a significant effect on profitability. The study concluded that there is a positive relationship between the EO and the profitability of real estate firms, and recommended that the utilisation of EO dimensions will lead to an improvement in the profitability of the real estate firms.
\end{abstract}

Keywords: Entrepreneurial orientation, EO- dimensions, firms performance, profitability, real estate firms

\section{Introduction}

In a competitive environment of today, the importance of Entrepreneurial Orientation (EO) on the performance of any business cannot be over emphasised. This is manifest in the rapid diffusion throughout the strategy literature (Carton, 2004). Wiklund and Shepherd (2005), Hakala (2011), noted that different strategic orientation of business such as EO, Market Orientation (MO), Customer Orientation (CO), Learning Orientation (LO) and Technology Orientation (TO) have gained considerable attention from both practicing managers and management scholars in which 
EO is identified as a key predictor for organisational success as well as a factor that lead to higher performances. It is further argued that firms that possess higher levels of EO will perform better than those with the lower level of EO (Wiklund \& Shepherd, 2005; Rhodes, Hung, Lok, Lien \& Wu, 2008; Rauch, Wiklund, Lumpkin, \& Frese, 2009). Therefore, the investors need to be entrepreneurial by incorporating EO into their practice, in order to survive and successfully compete, especially within fast-changing industries (Carton, 2004).

EO is a construct that has received much scholarly attention within the field of entrepreneurial literature and strategic management for the past two decades (Rauch et al., 2009; Miller, 2011). Lumpkin and Dess, (2001) defined EO as the strategy-making process that provides organisation with a basis for entrepreneurial decisions and actions. The entrepreneur is the decision-maker in the business that seeks, for the opportunity and undertakes risk. It has also been defined in different ways by scholars, but generally seeks to capture an organisational decision-making proclivity to engage in new, innovative, and entrepreneurial activities (Covin \& Wales, 2012). Such a proclivity is often beneficial for organisations operating in capital-intensive businesses in the for-profit arena such as real estate, where continual entrepreneurial principles are required to achieve and sustain a competitive advantage. EO reflects the behaviour of entrepreneurs such as innovativeness, pro-activeness, competitive aggressiveness, risk-taking, and autonomy (Rauch et al., 2009). The entrepreneurs have to be innovative while involving innovation of products, services, and process; need to be more proactive, be risk-oriented, competitive aggressive to overcoming a threat in a competitive market place and bringing forth a business vision from inception to completion.

Studies on EO have focused on other issues, for instance, Balan and Lindsay (2010) innovation capability, entrepreneurial orientation and performance in hotels; Olaniran (2016) firms in the Nigerian Stock Exchange; Ndungu (2014) information security and firms' performance; Olowofeso and Ale (2019) EO and performance of hospitality industry; Olubiyi, Egwakhe, Amos and Ajayi (2019) firm profitability in Lagos, Nigeria. Unfortunately, the effect to extend this EOperformance relation to the real estate business is still low. This study made great contributions towards the understanding of EO and the multidimensional nature of the construct in other sectors such as real estate. The study contributed to the research gap on EO by analysing the effect of the EO dimension on the profitability of real estate firms in South West, Nigeria.

\section{Literature Review}

\section{Entrepreneurial Orientation (EO)}

Entrepreneurial orientation can be described as a process by which organisation adopt a new method or opportunities and take responsibility to affect a change of the firms (Morris et al., 1996). It can also be defined as a strategy adopted by the firm in other to gain a competitive advantage over other firms (Rauch et al., 2009). EO of a firm is considered to be a good measure to explore opportunities in the market (Zahra \& Garvis, 2000). According to Rauch et al., (2009) a firm can be referred to as an entrepreneurial firm when it offers products and services above average into a new market. In the literature, $\mathrm{EO}$ of a firm consists of five dimensions; innovativeness, proactiveness, competitive aggressiveness, risk-taking, and autonomy (Lumping \& Dess, 1996). These five EO-dimensions were used in this study.

Innovativeness is referring to as the most important key component of entrepreneurship. It reflects the willingness to support creativity in introducing new products/ services, and novelty in developing a new product (Lumping \& Dess, 1996). Pro-activeness is defined as a way of anticipating future demand and opportunities in the market. Firms can be proactive by seeking new opportunities and participating in emerging markets by introducing new products and brands before their competitors (Venkatraman, 1989). Firms that respond to market changes 
instantly perform better than their rivals and they become leaders of the industry with opportunities they find before their rivals (Hughes \& Morgan, 2007). The propensity of a firm to intensely change its competitors and achieve entry or improve position in the market place, that is, to outperform industry rivals is known as competitive aggressive (Lumpkin \& Dess 1996). The reflection of activities of entrepreneurial firms such as incurring a heavy debt of making large resources commitment, in the interest of obtaining high returns by seizing opportunities in the marketplace is known as risk-taking propensity (Lumpkin \& Dess, 1996). This is a crucial factor that differentiates risk-taking from others because it can create losses and inconsistencies in the performance (Morris \& Kuratko, 2002). It is the behavioural dimension of an EO along which opportunity is pursued (Lumpkin \& Dess, 1996). Autonomy is an independent action by an individual or a term focused on creating a business concept and carrying it through to completion. According to Mintzberg and Waters (1985), entrepreneurs are strong leaders because their decision-making processes require decisive and risky actions, so entrepreneur autonomy is related to freedom of entrepreneurs, free actions, and independent decision making (Lumpkin \& Dess, 1996).

\section{Profitability of the firm}

Profitability is defined as the ratio of measure of the performance of the firm. This is the firm's ability to generate earnings for a certain period. According to Farah and Nina (2016), it helps the managers to develop an effective profitability strategy for the firms. For any profit-oriented firm to survive and maximizing its goal of business, there is need for effective profitability strategy which is the key issue for business survival (Ambad \& Wahab, 2013; Żur, 2013; Mule, Mukras \& Nzioka, 2015; Farah \& Nina, 2016; Neneh, Van- zyl \& Van- Noordwyk, 2016). Therefore, to achieve higher profitability, the manager must put in place a strategy that will fit into today rapidly changing business environment As mentioned above, in this study, the dependent variable, real estate performance, as measured by performance indicators (profitability) using subjective perceptions of the manager (Lopez- Gamero et al., 2009). This system was employed in the study because all the managers of the firms investigated are private firms and their owners are not obligated to give objective data of their firms to the research team. As a result, subjective measures became an acceptable substitute.

\section{Entrepreneurial orientation and profitability of the firms}

EO a found to be closely associated with the profitability of any business and considered an important component of successful organisaiton (Zahra \& Garris, 2000; Autonic \& Hisrich, 2001; Wiklund \& Shephered, 2005). Wales, Gupta, and Mousa (2011) argued that EOs effect on firm performance in terms of growth and profitability, especially in the hostile environmental conditions. EO was considered an important strategy in the process of improving the performance of the firms and a catalyst for the manager to act entrepreneurially (Okangi, 2019). Okangi (2019) argued that EO- dimension innovativeness and risk-taking have both significant and positive effect on the profitability of the firms while proactiveness has a negative and significant effect on the profitability of the firms. According to disruptive innovation theory, a new market and value proposition is as a result of the innovativeness of the firm. Deploying a destructive product innovation will lead to an improvement in the profitability of the firm (Dwyer \& Ofori, 2010; Slaughter. 2010; Wang \& Altinary, 2012).

A firm needs to be innovative in order to improve the quality of its products, services, and position in the market (Lim et al., Setiawan, Erdogan \& Ogunlana, 2012). Firms that put more effort into innovation will perform better than those that did not put more effort into innovation in terms of cost efficiency and increase productivity. (Lim et al., 2010; Ketchen \& Short, 2012). 
Proactiveness will enable the firm to pursue opportunities and achieve more profit than those that are not proactive in the market (Lumpkin \& Dess, 1996). This is because 'the higher the level of proactive in the business the higher the level of profit realised in such a business' (Casillas \& Moreno, 2010). The firm's ability in forecasting future market needs, provides that firm with an avenue of undergoing required changes that can help it in taking advantage of rivals in the market (Morgan \& Strong, 2003). Pro-activeness "equips firms with the ability to respond positively to market opportunities" (Kreiser et al., 2002). The positive effects of pro-activeness on the profitability of firms were also exhibited by Fairoz et al., (2919), when they measure the link that exists between the dimensions of EO and firm performance. Likewise, Kasumawardhani, McCarthy and Perera (2009), also found a positive and significant impact of pro-activeness on the profitability of the firms. Another study by Farja, Gimmon and Greenberg (2016) indicated that the higher the level of pro-activeness in a company, the higher the level of growth and profit realized in such companies.

Empirical findings show a positive and significant relationship between the risk-taking and profitability of the firms (Wiklund \& Shepherd, 2005; Kasumawardhani et al., 2009; Casillas \& Moreno, 2010; Wang \& Yen, 2012; Peng, 2015; Gibb \& Haar, 2019). Firms with higher risk profile experience, higher financial rewards (Gibb \& Harr, 2010). Firms that are able to commit significant resources to projects with high risks has the advantage of realizing higher outputs in terms of incomes generated (Ambad \& Wahab, 2013). However, some findings were unable to find a significant positive association between $\mathrm{EO}$ and profitability of the firm (George et al., 2001; Tang \& Koveos, 2004; Zainol \& Daud, 2011; Olowofeso, 2020). Interestingly, some contradicting results have been obtained in studies performed by Soininen (2012), in which they found EO as an individual construct did not positively relate to profitability. Dyzomonda and Masocha (2018) also show that profitability growth was not found to be significantly and positively related to EO. Due to the inconsistency in the literature on the effect of EO on the profitability of firms, the study hypothesis as follows:

$\mathrm{H}_{01}$ There is no significant effect of EO on the profitability of real estate firms in South West, Nigeria.

\section{Methodology}

The method employed in the study was a survey design and the population comprised of 967 registered Real Estate Development Companies (REDC) and 464 registered and Practicing Estate Surveyors and Valuers (PESV) in the South West, Nigeria, making a total of 1431 respondents. A sample size of 501 was determined using census approach for the firms in Ogun, Ondo, Ekiti, Oyo and Osun States. This was because the sample population of these states were within a manageable size and could easily be reached. They were all taken as part of the sample for the study, because of the large number of population of REDC and PESV in Lagos State, the study adopted Kothari (2004) formula to determine the sample size of the respondents in Lagos State. A structured questionnaire designed in the Likert scale method was adapted, validated and used to collect data for the study. Out of 501 copies of the questionnaire distributed 392 copies were returned for the analysis. The reliability test of the variables was determined using Cronbach's alpha and all the variables yielded above 0.7. Data were analyzed using both descriptive and inferential statistics. 
Table 1: Questionnaires Distributed and Returned

\begin{tabular}{|c|c|c|c|c|c|c|c|}
\hline State & $\begin{array}{l}\text { Distributed } \\
\text { Questionnair } \\
\text { es for REDC }\end{array}$ & $\begin{array}{l}\text { Returned } \\
\text { Questionnair } \\
\text { es for REDC }\end{array}$ & $\begin{array}{l}\text { Distributed } \\
\text { Questionnair } \\
\text { es for PESV }\end{array}$ & $\begin{array}{l}\text { Returned } \\
\text { Questionnair } \\
\text { es for PESV }\end{array}$ & $\begin{array}{l}\text { Total } \\
\text { Distributed } \\
\text { Questionnair } \\
\text { es }\end{array}$ & $\begin{array}{l}\text { Total } \\
\text { Returned } \\
\text { questionnair } \\
\text { es }\end{array}$ & $(\%)$ \\
\hline Lagos & 264 & 221 & 106 & 83 & 370 & 304 & 82 \\
\hline Ogun & 5 & 4 & 12 & 10 & 17 & 14 & 83 \\
\hline Ondo & 6 & 3 & 29 & 22 & 35 & 25 & 71 \\
\hline Ekiti & 5 & 2 & 6 & 4 & 11 & 6 & 55 \\
\hline Оуо & 18 & 10 & 29 & 19 & 47 & 29 & 62 \\
\hline Osun & 6 & 3 & 15 & 11 & 21 & 14 & 67 \\
\hline Total & 304 & 243 & 197 & 149 & 501 & 392 & 78 \\
\hline
\end{tabular}

Source: Field Survey, 2020

\section{Reliability of the Research Instrument}

Reliability refers to the consistency of scores that the same person would obtain if they were to take the test at the other times or under different conditions (Kothari, 2004). In other to ensure the internal consistency of the instrument and extent to which the measurement is free from viable errors, a reliability test was conducted on the instruments using Cronbach's alpha. When the variables were examined, the overall result of analysis indicated that the Cronbach's alpha of the construct ranges from 0.722 to 0.899 . Therefore, none of the items/variables were dropped from the study. Pallant (2011), and Hair, Hult, Ringle and Sarstedt (2010), asserted that Cronbach's Alpha greater than 0.7 can be accepted for analysis. The reliability result of this study has revealed that the variables of this research as listed in Table 2 are appropriate and used in this study.

Table 2: Reliability Test

\begin{tabular}{ll}
\hline Construct & Overall Cronbach's alpha \\
\hline Innovativeness & 0.869 \\
Pro-activeness & 0.847 \\
Competitive aggressiveness & 0.722 \\
Risk taking & 0.838 \\
Autonomy & 0.818 \\
Performance & 0.890 \\
\hline
\end{tabular}

Source: Field Survey, 2020

\section{Model Specification}

In this study, real estate firms' performance was measured with profitability using the constructs in the independent variables. Innovativeness was measured using nine constructs, pro-activeness was measured using four constructs, competitive aggressiveness was measured using four constructs, while risk-taking was measured using five constructs and autonomy was measured using five constructs. The details of the variables used in the model were shown in the model specification below. The effects of EO on performance were examined on the basis of the following linear model.

$\mathrm{Y}=\mathrm{a}+\beta_{1} \mathrm{INOV}+\beta_{2} \mathrm{PROV}+\beta_{3} \mathrm{COMA}+\beta_{4} \mathrm{RISK}+\beta_{5} \mathrm{AUTO}+\ell \mathrm{i}$

Where a = constant,

$\mathrm{Y}$ is the performance of real estate firms (Profitability) and

INOV $=$ Innovativeness, $\mathrm{PROV}=$ Pro-activeness, $\mathrm{COMA}=$ Competitive aggressiveness, $\mathrm{RISK}=$ Risk-taking, $\mathrm{AUTO}=$ Autonomy,$\ell i=$ is the error term. 


\section{Result and Discussion of the Findings}

To determine the effective profitability of the firms, a multiple regression model for the independent and dependent variables was developed. The independent variables are the five EOdimensions of innovativeness, pro-activeness, competitive aggressiveness, risk-taking, and autonomy while the dependent variable was the profitability of the real estate firms. The correlation $(\mathrm{R})$ value of the entire EO (all the five independent variables) and profitability was 0.794. This indicates a positive relationship between the variables. This implies that when the EO variables increase, the profitability of the firms will also increase, and vice versa. The R-square (which indicates the extent to which profitability was explained by the EO) was 0.630 . This shows that $63 \%$ of the profitability was explained by the EO variables: The analysis of the variance indicates that the overall model was statistically significant $\mathrm{P}<0.05$. Hence $\mathrm{H}_{01}$ which says; there is no significant effects of EO on the profitability of real estate firms in South West, Nigeria is rejected. This implies that the adoption of EO - dimensions by the real estate firms will lead to an increase in the profitability of the firms. The study is in line with the study of Zur (2013), and Neneh et al., (2016), that there is a relationship between the EO and the profitability of the business but disagree with the finding of Dzomonda and Masocha (2018), who find that there is no significant relationship between EO and profitability. Table 3, shows the coefficient value for all the independent variables, the results revealed that innovativeness has a positive beta coefficient of 0.731 . Indicates that holding all other things constant (ceteris paramus), profitability would increase by $73.1 \%$ when there is an increase in the innovativeness by $100 \%$ this was statistically significant at $\mathrm{P}<0.05$. Innovativeness can help firms to pursue "new opportunities" (Wang \& Altinay, 2012; Wiklund \& Shepherd, 2005) and contributes significantly to the success of the firms (Gambatese \& Hallowell, 2010, Lim et al., 2010; Slaughter, 2010). The coefficient value for proactiveness was 0.203 , indicating that $20.3 \%$ increase in profitability will also lead to an increase in the pro-activeness by $100 \%$. This was also statistically significant at $\mathrm{P}=0.004$. Competitive aggressiveness has a negative coefficient value of -0.331 and significant at a value of $\mathrm{P}=0.000$. Indicating that 0.331 increases in the independent variables will lead to decreases in profitability. The result of risk-taking also has a coefficient value of 0.026 and a significant value of $P=0.722$, indicating that $2.6 \%$ increase in profitability will also lead to an increase in risk-taking by 100 . Autonomy has a coefficient value of -0.098 and a significant value of $\mathrm{P}=0.126$ and an indication that the profitability of the firm would increase by $2.6 \%$ when the risk-taking was increased by 100 .

Table 3: Results of Regression Analysis: Effect of EO on Profitability

\begin{tabular}{|c|c|c|c|c|c|}
\hline \multirow[b]{2}{*}{ Model } & \multicolumn{5}{|c|}{ Unstandardized Coefficients } \\
\hline & $\mathrm{B}$ & Std. Error & & $\mathrm{T}$ & Sig. \\
\hline (Constant) & 1.910 & 0.260 & 7.340 & & 0.000 \\
\hline INOV & $0.731^{* * *}$ & 0.096 & 7.645 & & 0.000 \\
\hline PROV & $0.203^{* * *}$ & 0.069 & 2.935 & & 0.004 \\
\hline COMA & $-0.331^{* * *}$ & 0.070 & -4.704 & & 0.000 \\
\hline RISK & 0.026 & 0.073 & 0.356 & & 0.722 \\
\hline
\end{tabular}




\begin{tabular}{lcccc}
\hline AUTO & -0.098 & 0.064 & -1.534 & 0.126 \\
Model indices & & & \\
$\mathrm{R}$ & 0.794 & & \\
$\mathrm{R}^{2}$ & 0.630 & & \\
Adjusted R $^{2}$ & 0.624 & & \\
F-Statistic & 39.206 & & \\
P- value & 0.000 & & & \\
& & & & \\
\end{tabular}

\section{*** significant at $1 \%$ level}

Source: Field Survey, 2020

The output in the regression in Table 3 represents the linear regression to establish the impact of $\mathrm{EO}$ on real estate firms in the study areas. The regression equation was therefore

$Y=a+\beta_{1} X_{1}+\beta_{2} X_{2}+\beta_{3} X_{3}+\beta_{4} X_{4}+\beta_{5} X_{5}+\ell i$

when the values from the regression Table 3 are computed, the model can be written as;

$\mathrm{Y}=\mathrm{a}+\beta_{1} \mathrm{INOV}+\beta_{2} \mathrm{PROV}+\beta_{3} \mathrm{COMM}+\beta_{4} \mathrm{RISK}+\beta_{5} \mathrm{AUTO}$.

Profitability $=1.910+0.731($ INOV $)+0.203($ PROV $)-0.331($ COMP $)+0.026($ RISK $)-0.098($ AUTO $)$.

\section{Discussion}

The position of the market and quality of its products and services, cost efficiency and productivity in the firms can be improved with the adoption of innovativeness (Lim et al., 2010; Ketchen \& Short, 2012; Setiawan et al., 2012). In general, innovativeness influences the performance of the firms (Gambatese \& Hallowell, 2010; Lim et al., 2010; Slaughter, 2010; Ketchen \& Short, 2012; Setiawan et al., 2012). The significant and positive relationship between innovativeness and firms performance was also indicated in several studies such as Lee and Lim (2009), Sasillas and Moreno (2010), Wang, Ahmad and Subari (2010), Kraus et al., (2012), Wang and Yen (2012), and Kraus (2013). A firm that adopts innovativeness was found to perform better than those that did not adopt innovativeness (Wiklund \& Shepherd, 2005; Rauch et al., 2009; Kraus et al., 2012). Firms also need to be proactive in pursuing opportunities in the market. The more proactive the firm is in capturing new business opportunities, the greater the profitability rates of the firm (Lumpkin \& Dess, 1996; Casillas \& Moreno, 2010). Firms need to be proactive to undergo changes that can help to take advantage over his competitors in the market (Morgan \& Strong, 2003). Pro-activeness "equips firms with the ability to respond positively to market opportunities" (Lumpkin \& Dess, 1996; Kreiser et al., 2002). Consequently, pro-activeness can improve the growth of a firm developing a new business model (Zahra \& Garvis, 2000). Fairoz et al., (2010) exhibited a positive effect of proactiveness on the profitability of firms. Likewise, Kasumawardhani et al., (2009) and Olubiyi et al., (2019) also found a significant and positive impact of proactiveness on the profitability of the firms. Another study Farja et al., (2016), indicated that the higher the level of pro-activeness in business, the higher the level of profit was realized in such a business. The result of the study also concurs to that of Arsed (2013), who discovered that innovativeness, pro-activeness and competitive aggressive has significant with the profitability of the business. Arshed observed that these variables are good predictors that affect the performance of the firms. The finding of the result shows that risk-taking did not significant with the profitability of the firms. This is in agreement with the study of Casillas and Moreno (2010), and Olowofeso (2020), who did not confirm that risk-taking positively influences the profitability of the business. But the finding disagrees with other studies such as Casillas and 
Moreno (2010), Gibb and Haar (2010), Wang and Yen (2012), Jalali et al., (2014), Peng (2015), and Olubiyi et al., (2019) who found a significant and positive relation between risk-taking and profitability. Based on the principle of risk-high return, firms that have a high appetite for high risk-high return projects are likely to be profitable by tapping into markets that are less congested by competitors.

Findings from the previous studies show that the intensity of risk taken by firms is associated with outcomes. For instance, Wiklund and Shepherd (2005), Kasumawardhani et al., (2009), Casillas and Moreno (2010), Wang and Yen (2012), Peng (2015), Gibb and Haar (2019) justify a positive and significant relationship between the effect of risk-taking and profitability of the firms that can commit significant resources to projects with high risks has advantage of realizing higher outputs in terms of incomes generated (Ambad \& Wahab, 2013). The finding of the result shows that autonomy did not significant with the profitability of the firms. This is in agreement with the study of Olubiyi et al., (2019) who found no significant relationship between the autonomy and profitability of SME.

The results revealed that innovativeness, pro-activeness and competitive aggressiveness have a significant relationship with the profitability of the firms. Innovativeness and pro-activeness have a significant and positive relationship with the profitability of real estate firms. This implies that both the creative ideas and market innovation supported and embraced by real estate firms in South West Nigeria were yielding the desired result in terms of profitability. Considering proactiveness, awareness of market signals and imitation and exploitation of new opportunities among real estate firms in the study area has a significant effect on the profitability of the firms. Competitive aggressiveness has a negative and significant relationship with the profitability of the business. However, risk-taking and autonomy have no significant relation to the profitability of the business. This suggests that there was no improvement in the profitability of the firms when these variables were applied. Risk-taking propensity exhibited by the firm in South West Nigeria shows no influence on the success of the firms. Similarly, despite the freedom to work for employees to act alone in the best interest of the firms, there was no improvement in profitability.

\section{Conclusion and Recommendations}

A positive relationship between the EO dimensions and profitability of the real estate firms was revealed in the study area with $R=0.794$ and $R^{2}$ of 0.630 . The overall model was statistically significant at $\mathrm{P}<0.05$, three of the independent variables (innovativeness, pro-activeness and risktaking) have a positive effect on the dependent variable while competitive aggressiveness and autonomy have a negative effect on the dependent variable. Based on the findings the study recommends that the utilization of EO dimensions will lead to improved performance of the real estate firms. Therefore, it is important for the government and the real estate investor to develop internal strategic measures that will promote the EO dimension in the management practices. The government and policymakers need to come up with a programme that could be tailored to helping the real estate firm and integrate EO strategic behaviour in their management practices. Future research of this nature should employ longitudinal research design which will allow more periods and opportunities to cover more geo-political zone in Nigeria, thereby achieving more robust data and findings for the study.

\section{Limitation of the Study}

The study has led to key findings on the influence of EO on the profitability of real estate firms in the study area; however, the study is without some limitations that need to be addressed in the future. The study is survey research, not longitudinal research; it only covered one geopolitical zone in the country (Nigeria). 


\section{References}

Aloulou, W., \& Fayolle, A. (2005). A conceptual approach of entrepreneurial orientation within a small business context. Journal of Enterprising Culture, 13(1), 21-45.

Ambad, S. N. A., \& Wahab, K. A. (2013). Entrepreneurial orientation among large firms in Malaysia: contingent effects of hostile environments. International Journal of Business and Social Science, 4(16), 96-107.

Antoncic, B., \& Hisrich, R. D. (2001). Intrapreneurship: Construct refinement and cross-cultural validation. Journal of Business Venturing, 16, 495-527.

Awang, A. B., Ahmad, Z. A., \& Subari, K. A. (2010). Entrepreneurial orientation among Bumiputera small and medium agro-based enterprises (Bsmaes) in West Malaysia: policy implication in Malaysia. International Journal of Business and Management, 5(5), 130.

Balan, P., \& Lindsay, N. (2010). Innovation capability, entrepreneurial orientation and performance in Australian hotels: An empirical study. Cooperative Research Centre for Sustainable Tourism.

Carton, R. B. (2004) Measuring organizational performance: An exploratory study. Unpublished Ph.D. Thesis, University of Georgia, Athens.

Casillas, J. C., \& Moreno, A. M. (2010). The relationship between entrepreneurial orientation and growth: The moderating role of family involvement. Entrepreneurship \& Regional Development, 22(3-4), 265-291.

Christensen, (1997). The innovator's dilemma when new technologies cause great firms to fail.

Covin, J. G., \& Slevin, D. P. (1989). Strategic management of small firms in hostile and benign environments. Strategic Management Journal, 10(1), 75-87.

Covin, J. G., \& Wales, W. J. (2012). The measurement of Entrepreneurial orientation. Entrepreneurship Theory and Practice, 1(1), 1-26.

Dzomonda, O., \& Masocha, R. (2018). Entrepreneurial orientation and growth nexus, a case of South African SMEs. Acta Universitatis Danubius, 14(7), 248-258.

Fairoz, F. M., Hirobumi, T., \& Tanaka, Y. (2010). Entrepreneurial orientation and business performance of small and medium scale enterprises of Hambantota District Sri Lanka. Asian Social Science, 6(3), 34-46.

Farah, M., \& Nina, S. (2016). Factors affecting the profitability of small-medium enterprises (SMEs) firm listed in the Indonesia Stock Exchange. Journal of Economics, Business and Management, 4(2), 132-137.

Farja, Y., Gimmon, E., \& Greenberg, Z. (2016). The effect of entrepreneurial orientation on SMEs growth and export in Israeli peripheral regions. New England Journal of Entrepreneurship, 19(2), 24- 40.

Gambatese, J. A., \& Hallowell, M. (2010). Enabling and measuring innovation in the construction industry. Construction Management and Economics, 29(6), 553-567.

Gathungu, J. M., Aiko, D .M., \& Machuki, V. N. (2014). Entrepreneurial orientation, networking, external environment and firm performance. European Scientific Journal, 10 (7), 107-118.

George, G., Wood, R. D., \& Khan, R. (2001). Networking strategy of boards: Implications for small and medium-sized enterprises. Entrepreneurship and Regional Development, 13(3), 269-285. 
Gibb, J., \& Haar, J. M. (2010). Risk-taking, innovativeness, and competitive rivalry: a three-way interaction towards firm performance. International Journal of Innovation Management, 14(5), 871- 891.

Hair, J. F., Black, W. C, Babin, B. J. (2010). Multivariate data analysis: A global perspective. Upper saddle. River new jersey, Pearson Prentice Hall.

Hakala, H. (2011). Strategic orientations in management literature: Three approaches to understanding the interaction between Market, Technology, Entrepreneurial and Learning Orientations, International Journal of Management Reviews, 13(2), 199-217.

Hughes, M., \& Morgan, R.E. (2007). Deconstructing the relationship between entrepreneurial orientation and business performance at the embryonic stage of firm growth. Industrial Marketing Management, 36, 651-661.

Jalali, A., Jaafar, M., \& Ramayah, T. (2014). Entrepreneurial orientation and performance: the interaction effect of customer capital. World Journal of Entrepreneurship, Management and Sustainable Development, 10(1), 48- 68.

Jantunen, A., Puumalainen, K., Saarenketo, S., \& Kyläheiko, K. (2005). Entrepreneurial orientation, dynamic capabilities and international performance. Journal of International Entrepreneurship, 3, 223-243.

Kasumawardhani, A., McCarthy, G., \& Perera, N. (2009). Framework of entrepreneurial orientation and networking: A study of SMEs performance in a developing country. Proceedings of the Australian and New Zealand Academy of Management Conference 1-16. Adelaide: Australian and New Zealand Academy of Management.

Keh, H. T, Nguyen T. T. M., \& Ng, H. P. (2007). The entrepreneurial orientation and marketing information on the performance of SMEs. Journal of Business Venturing 22(4), 592- 611.

Ketchen, D., \& Short, J. (2012). Strategic Management: Evaluation and Execution 1(2), 70-75, https://my.uopeople. edu/pluginfile.php/57436/mod book/chapter/122442/ BUS\%205117\%20strategic -management-evaluation.pdf. Accessed 7 April, 2018.

Kothari, C. R. (2004). Research methodology: Methods and techniques. (2nd ed.). New Age International Ltd. New Delhi.

Kraus, S. (2013). The role of entrepreneurial orientation in service firms: empirical evidence from Austria. The Service Industries Journal, 33(5), 427-444.

Kraus, S., Rigtering, J. P. C., Hughes, M., \& Hosman, V. (2012). Entrepreneurial orientation and the business performance of SMEs: a quantitative study from the Netherlands. Review of Managerial Science, 6(2), 161-182.

Kreiser, P. M., Marino, L. D., \& Wearver, K. M. (2002). Assessing the psychometric properties of Entrepreneurial orientation scale: A multi-country analysis. Entrepreneurship Theory and Practice 26(4), 71-94.

Lim, J. N., Schultmann, F., \& Ofori, G. (2010). Tailoring competitive advantages derived from innovation to the needs of construction firms. Journal of Construction Engineering and Management, 136(5), 568-580.

Lumpkin, G. T., \& Dess, G. G. (1996). Clarifying the entrepreneurial orientation construct \& linking it to performance. Academy of Management Review, 21(1), 135-172. 
Lumpkin, G. T., \& Dess, G. G. (2001). Linking two dimensions of entrepreneurial orientation to firm performance: The moderating role of environment and industry life cycle. Journal of Business Venturing, 16(5), 429-451.

Lumpkin, G. T., Cogliser, C. C., \& Schneider, D. R. (2009). Understanding and measuring autonomy: An entrepreneurial orientation perspective. Entrepreneurship Theory and Practice, (1), 47-69.

Madsen, E. L. (2007). The significance of sustained entrepreneurial orientation on performance of firms: a longitudinal analysis. Entrepreneurship \& Regional Development, 19(2), 185-204.

Miller, D. (2011). A reflection on entrepreneurial orientation research and some suggestions for the future, entrepreneurship. Theory and Practice, 35(6), 873-894.

Mule, R. K., Mukras, M. S., \& Nzioka, O. M. (2015). Corporate size, profitability and market value: An econometric panel analysis of listed firms in Kenya. European Scientific Journal, 11(13), 376-396.

National Bureau of Statistics NBS. (2015). Nigerian real estate sector, Summary Report 2010- 2012' 2015 Real Estate outlook in Nigeria, February.

Ndung'u, S. I. (2014). Moderating role of entrepreneurial orientation on the relationship between information security management and firm performance in Kenya. Unpublished Ph.D. Thesis Submitted to Jomo Kenyatta University of Agriculture and Technology, Kenya.

Neneh, B. N., Van-Zyl, J. H., \& Van-Noordwyk, A. (2016). Gender differences in entrepreneurial orientation and performance: Evidence from South Africa. Conference paper submitted at the Southern African Institute for Management Scientists (SAIMS), 4-7 September 2016, Pretoria, South Africa.

Okangi, F. P. (2009). The impacts of entrepreneurial orientation on the profitability growth of construction firms in Tanzania. Journal of Global Entrepreneurship Research 9(I4), 1-23.

Olaniran, O. (2016). Role of entrepreneurial orientation on the performance of firms in the Nigerian stock exchange. Unpublished Ph.D. Thesis Submitted to Jomo Kenyatta University of Agriculture and Technology.

Olowofeso, E. (2020). Analysis of entrepreneurial orientation on the performance of real estate firms in South West, Nigeria. Unpublished Ph.D. thesis, Department of Project Management Technology, The Federal University of Technology, Akure.

Olubiyi, T. O., Egwakhe, A. J., Amos, B., \& Ajayi, A. A. (2019). Entrepreneurial orientation and firm profitability: Evidence from Lagos State Nigeria. Journal of Business and Management, 2(6), 42-54.

Pallant, J. (2011). SPSS Survival Manual. A step by step guide to data analysis using SPSS (4th ed.). Melbourne: Open University Press.

Rauch, A., Wiklund, J., Lumpkin, G. T., \& Frese, M. (2009). Entrepreneurial orientation and business performance: An assessment of past research and suggestions for the future. Entrepreneurship Theory and Practice, 33(3), 761-787.

Rhodes, J., Hung, R., Lok, P., Lien, B. Y., \& Wu, C. M. (2008). Factors influencing organizational knowledge transfer: Implication for corporate performance. Journal of Knowledge Management, 12(3), 84-100. 
Rauch, A., Wiklund, J., Lumpkin, G. T., \& Frese, M. (2009). Entrepreneurial orientation and business performance: An assessment of past research and suggestions for the future. Entrepreneurship Theory and Practice, 33(3), 761-787.

Setiawan, H., Erdogan, B., \& Ogunlana, O. (2012). Corporate entrepreneurship for contracting companies: the current issues. In Proceedings 28th Annual ARCOM Conference, 3-5.

Slaughter, E. S. (2010). Implementation of construction innovations. Building Research and Information, 28(1), 2-17.

Soininen, J. (2012). Entrepreneurial orientation in small and medium-sized enterprises during the economic crisis in Finland. Management Research Review, 35(10), 927 - 944.

Tang, L., \& Koveos, E. (2004), Venture entrepreneurship, innovation entrepreneurship and economic growth. Journal of Developmental Entrepreneurship, 9(2), 161-171.

Venkatraman, N. (1989). Strategic orientation of business enterprises: the construct, dimensionality, and measurement. Management Science, 35(8), 942-962.

Wainaina, A .W. (2017). Effect of entrepreneurial orientation on the growth of micro finance institutions based in Nairobi, Kenya. Unpublished Ph.D. Thesis Submitted to Jomo Kenyatta University of Agriculture and Technology, Nairobi, Kenya.

Wales, W. J., Gupta, V. K., \& Mousa, F. T. (2011). Empirical research on entrepreneurial orientation: An assessment and suggestions for future research. International Small Business Journal, 3(4), 357-383.

Wang, C. L., \& Altinay, L. (2012). Social embeddedness, entrepreneurial orientation and firm growth in ethnic minority small businesses in the UK. International Small Business Journal, 30, 3-23.

Wang, Z., \& Wang, N. (2012). Knowledge Sharing, innovation and firm performance, Expert Systems with Applications 39(10), 8899-8908.

Wang, H., \& Yen, Y. (2012). An empirical exploration of CEO and performance in Taiwanese SMEs: a perspective of a multi-dimensional construct. Total Quality Management and Business Excellence, 23(9), 1035-1044.

Wiklund, J., \& Shepherd, D. (2005). Entrepreneurial orientation and small business performance: A configurational approach. Journal of Business Venturing, 20(1), 71-91.

Zahra, S. A., \& Covin, J. G. (2000). Contextual influences on the corporate entrepreneurshipperformance relationship: A longitudinal analysis. Journal of Business Venturing 10(1), 4358.

Żur, A. (2013). Entrepreneurial orientation and firm performance- Challenges for research and practice. Entrepreneurial Business and Economics Review, 1(2), 7-28. 